\title{
MICROTUBULAR NETWORK OF THE GELATINOUS EGG ENVELOPE WITHIN THE EGG RIBBON OF EUROPEAN PERCH, PERCA FLUVIATILIS L.
}

\author{
Krzysztof FORMICKI*, Izabella SMARUJ, Joanna SZULC, and Aleksander WINNICKI \\ Division of Fish Anatomy and Embryology, West Pomeranian University of Technology, Szczecin, Poland
}

Formicki K., Smaruj I., Szulc J., Winnicki A. 2009. Microtubular network of the gelatinous egg envelope within the egg ribbon of European perch, Perca fluviatilis L. Acta Ichthyol. Piscat. 39 (2): 147-151.

\begin{abstract}
Background. After their deposition in water, eggs of perch form characteristic, long gelatinous ribbons (strands) floating within the water column. The ultrastructure of the external gelatinious egg envelope of members of the family Percidae was believed to be amorphous. The aim of the presently reported study was to describe the ultrastructure and function of the gelatinous egg envelope composing the perch egg ribbon.

Materials and Methods. Fresh eggs of European perch, Perca fluviatilis L., were collected, in the form of egg ribbons, from females caught at the spawning grounds on the Odra River side canal Dziewoklicz, within the city limits of Szczecin, Poland. After fertilization eggs were fixed in $4 \%$ formaldehyde. In the laboratory, the commonly accepted techniques (dehydration, critical-point drying, sputter coating) were used to prepare samples for examination with a scanning electron microscope (SEM). The observations were photographically documented.

Results. Closely below the surface of the gelatinous egg ribbon we observed a network of microtubules. These microtubules opened at the egg ribbon surface in the form of ring-like or nozzle-like pores.

Conclusion. The gelatinous egg envelope of perch is a complex microtubular network that likely performs a skeletal role for the egg ribbon. Our results also suggest that the regular surface openings of the aforementioned network may play an attachment function (micro-suckers) reciprocally between eggs and between eggs and other objects, thereby facilitating the fastening the eggs to underwater vegetation.
\end{abstract}

Keywords: European perch, Perca fluviatilis, gelatinous egg envelope, egg ribbon, microtubular network

\section{INTRODUCTION}

The embryonic development of the majority of teleost fishes takes place in an environment, external to the maternal organism. To facilitate such development a number of evolutionary adaptations exist that counteract adverse environmental effects and favour factors beneficial to the developing embryo (e.g., factors affecting suitable spawning time, spawning performance, nest construction, egg deposition, parental care, and egg structure) (Depêche and Billard 1994, Chen et al. 2007, Fava and Toledo-Piza 2007, Fishelson and Gon 2008, Jiang et al. 2010).

The perciform fish egg has a complex structure. Its central (live) is composed of vitelline cytoplasm surrounded by a semi-permeable vitelline membrane and a set of additional envelopes. These envelopes closely surrounding the egg are primary- and secondary products of the ovary (Depêche and Billard 1994, Britz and Cambray 2001, Bless and Riehl 2002). They are elastic and resistant to mechanical stimuli (Davenport et al. 1986). Additionally, the egg is covered by a limp, delicate, gelatinous coat that surrounds the egg by the end of oogenesis and after its discharge form the oviduct. The size, shape, and the weight of egg cells are determined by their taxonomic affiliation (Riehl and Schulte 1977, Riehl 1978, Mikodina 1987, Britz and Bartsch 1998, Britz and Cambray 2001, Bless and Riehl 2002, Depêche and Billard 1994, Fausto et al. 2004, Chen et al. 2007, Fava and Toledo-Piza 2007, Fishelson and Gon 2008, Jiang et al. 2010).

The gelatinous layer-distinct in some teleost fishes - is usually formed between the radial layer of the egg shell and the follicular cells of the ovary follicle and has been treated as an amorphous structure (Bonsignorio et al. 1996, Jiang et al. 2010) It contains high amounts of glycoprotein (Kobayashi 1982, Scapigliati et al. 1995, Chiou et al. 2004) as occurs also in the zona radiata externa (Mansour et al. 2009). Immediately after the egg deposition this gelatinous substance quickly acquires water and swells. This contributes to a characteristic "sticky" appearance of eggs, helping them to attach to underwater vegetation.

A good example of the above-mentioned phenomenon is the European perch, Perca fluviatilis L., which deposits its eggs in the form of long $(0.5-5.5 \mathrm{~m})$, openwork, gelat-

\footnotetext{
* Correspondence: Prof. dr hab. Krzysztof Formicki, Katedra Anatomii i Embriologii Ryb, Zachodniopomorski Uniwersytet Technologiczny, ul. Kazimierza Królewicza 4, 71-550 Szczecin, Poland, phone: +48 91449 6665, e-mail: krzysztof.formicki@zut.edu.pl
} 
inous egg ribbons, attached to submerged aquatic vegetation (Flügel 1967, Riehl and Patzner 1998). While in water, perch eggs form a gelatinous structure, which is greatly enhanced by ovarian fluid (Mansour et al. 2009). Similar, although not identical gelatinous envelopes are produced in the eggs of many other teleost fish species such as: vimba, Vimba vimba (L.); lumpsucker, Cyclopterus lumpus L.; white bream, Blicca bjoerkna L.; Chinese perch, Siniperca chuatsi (Basilewsky, 1855); spirlin, Alburnoides bipunctatus (Bloch, 1782); and roach, Rutilus rutilus (L.) (see: Davenport and Lonning 1983, Patzner and Glechner 1996, Britz and Bartsch 1998, Szulc 2007, Jiang et al. 2010).

The aim of this paper was to describe the newly found, three-dimensional structures within the gelatinous layer of the perch egg and to explain their role in the process of embryogenesis and its success.

\section{MATERIALS AND METHODS}

Gametes of European perch, Perca fluviatilis L., were collected in April 2008 from mature specimens at the spawning grounds on the Odra River side canal Dziewoklicz, within the city limits of Szczecin. The eggs and sperm from 11 males and 11 females were gently squeezed out into individual test tubes. The test tubes were transported in thermos flasks held in isothermal chests, chilled by reusable "ice" packs to ensure stable temparature. In the laboratory the eggs from each female were fertilized with the pooled sperm (from 11 males), and placed in 300-mL glass beakers in an isothermal laboratory. The eggs were incubated in constantly aerated water at $12 \pm 0.5^{\circ} \mathrm{C}$.
Sections of the egg ribbon, destined for scanning electron microscopy (SEM), were sampled 2 and $24 \mathrm{~h}$ after egg fertilization and fixed in $4 \%$ buffered formaldehyde. The samples from each female were dehydrated in an alcohol and acetone series, $\mathrm{CO}_{2}$ critical-point dried, mounted on SEM stubs, and sputter coated with gold palladium (Glauert 1981) and observed under a scanning electron microscope (FEI Quanta 200). The observations were photographically documented. The egg strand from each female was photographed (in vivo) under light microscope.

In this description of our results, we have chosen to omit general details and focus on details of unknown and hitherto undescribed egg features.

\section{RESULTS}

Our observations suggest that the gelatinous envelope of the perch egg possesses a complex structure. Upon eggs deposition in the water, acquiring substantial amounts of water, and swelling they form an openwork, gelatinous ribbon with evenly distributed eggs (Fig. 1), containing developing embryos. Scanning electron microscope examination of the surface of the gelatinous envelope of eggs sampled from the egg ribbon revealed a number of structural surface and envelope-core details which were arranged regularly and showed a repeated pattern. Examination of individual sections revealed internal, tubular structures, just beneath the outer surface of the gelatinous envelope (Fig. 2), some of them opening onto the surface with ring-like orifices. (Figs. 3-5). Surface examination of the gelatinous layer revealed a pattern of

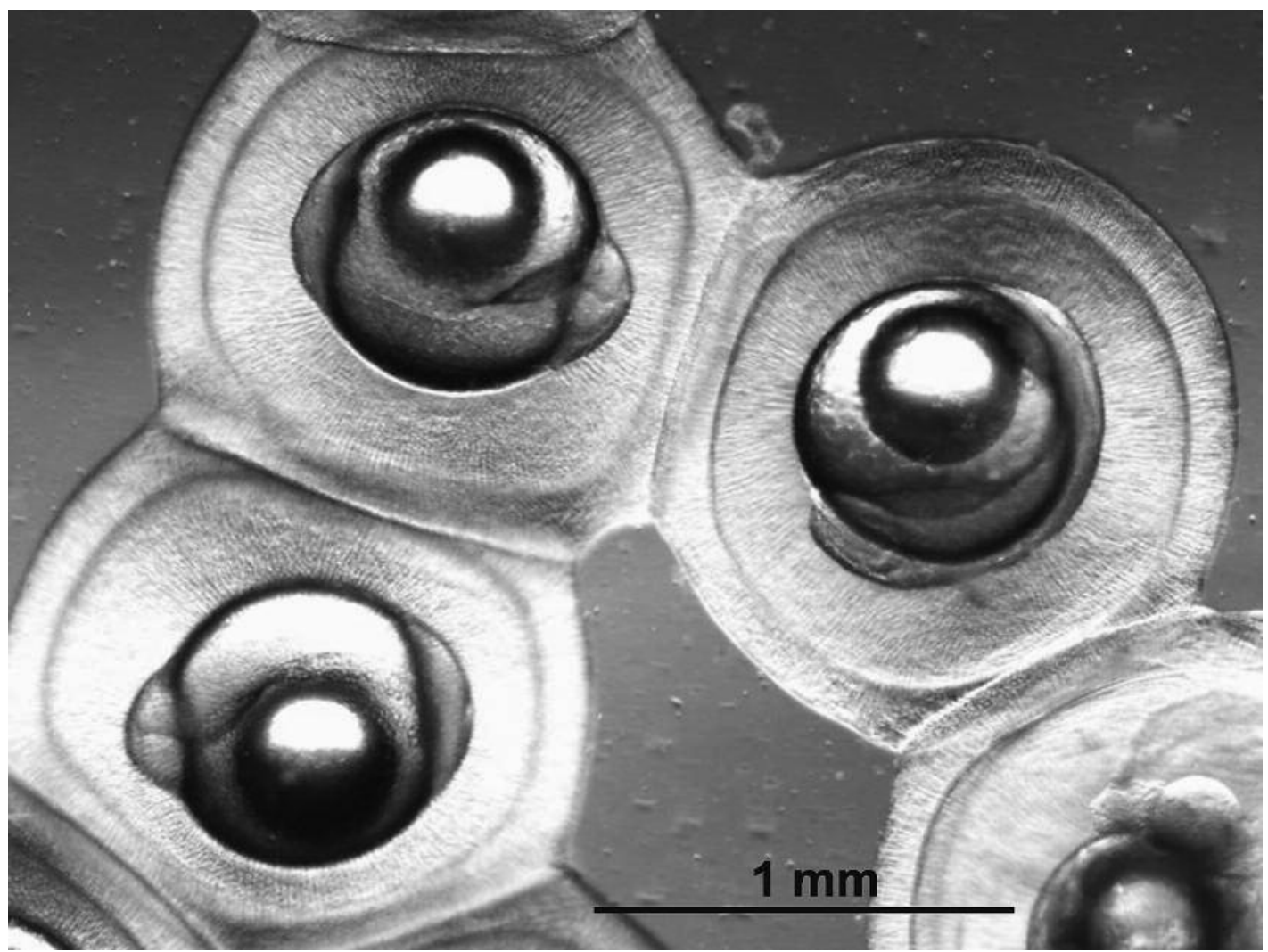

Fig. 1. European perch, Perca fluviatilis L.; developing eggs, each surrounded by a gelatinous egg envelope 

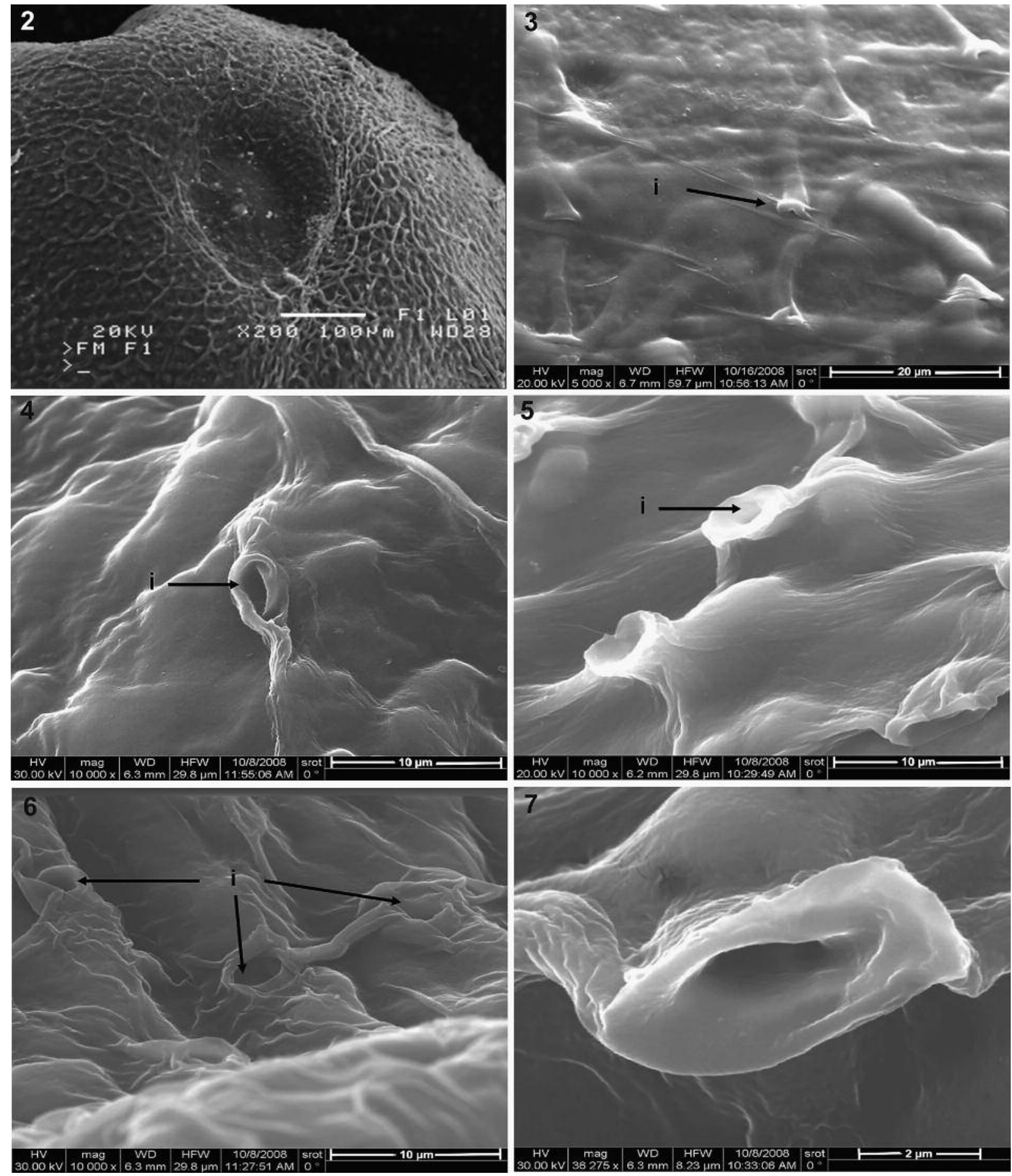

Fig. 2-7. Gelatinous layer of egg envelope of European perch, Perca fluviatilis; Fig. 2. Reticular network of microtubules in the gelatinous layer; Fig. 3. Sub-surface microtubules and their pores (i) in the gelatinous layer; Figs. 4, 5. Pores (i) of the microtubular system; Fig. 6. Diversified shape of pores (i) of the microtubular network; Fig. 7. Nozle-like opening of the microtubular network

densely distributed nozzle-like openings of the microtubular network (Figs. 6, 7). These structures were not homogeneously distributed within the layer being more abundant in some areas than in others.

\section{DISCUSSION}

The present findings of a three-dimensional network of microtubules and their specific nozzle-like pores con- tradict the presumption about the alleged uniform structure of the gelatinous layer of the perch egg (Rizzo et al. 2002). Microtubules are common cytoskeletal structures, occurring as well in intercellular spaces of numerous organisms including fishes. They are present under the embryonic shield (Jesuthasan and Strähle 1997) and in the chromatophores (Schliwa et al. 1979) of many fish species. Microtubular systems may also be present in products 
of genital organs, such as ovary and oviduct, of fish (Mooi 1990). We believe that the springy, elastic, but at the same time, limp structures, may aid the flow or pulsation of fluids inside them. Moreover, the hydrophilous nature of their colloids, present inside the tubules confer an inner turgor (Bogucki 1930, Winnicki 1967, Davenport and Lønning 1983). As a consequence, the network of tubules inside the gelatinous envelope of an egg is suspected of creating a specific, three-dimensional scaffolding, carrying non-structural constituents of the gel.

In view of the above, we assume that the principal role of the microtubular network in the gel of the egg ribbon of perch is its skeletal function. This said, however, the microtubules may also play a secondary role regarding egg ribbon attachment. Certainly the nozzle-like pores of the microtubules resemble small suckers. After the eggs are discharged from the maternal organism, the hydrophilous colloids, present inside the tubules, acquire water, thus creating a negative pressure in the tubules which draws water in through the pores. We suggest that this hydrostatic process effects a thorough reciprocal attachment of eggs as well as the attachment of the egg ribbon to the vegetation. Such an interpretation of fish eggs being surrounded by a natural gel and the method used to attach to the vegetation challenges the commonlyheld view of "stickiness" of the eggs being a phenomenon caused by simple sticky lumps of gelatinous material.

Specific filaments, present in the inter-egg gel within the ribbon, were observed using a dissecting microscope by Mansour et al. (2009). We elaborated on those findings, contributing additional ultrastructural data. Mansour et al. (2009) suggested that the ovarian fluid of perch is an important element of this egg attachment and formation of this gelatinous structure of egg ribbon. Our finding, confirm that the microtubular network is responsible for reciprocal attachment of individual eggs.

It should be emphasized that any extra layer surrounding the egg (in this case a hypothetical "sticky" substance) would constitute an evolutionary disadvantage, through obstructing oxygen penetration from water to the egg. The explanation proposed here helps to understand the "stickiness" as being a micro-attachment event caused by sucking action of nozzle-like pores of the microtubules. The attachment of ring-like or nozzle-like attachment structures of the microtubular network facilitates spreading of the egg ribbon on submerged aquatic vegetation or on a solid substrate (Zeh et al. 1989, Gillet and Dubois 1995, Mansour at al. 2008), which in turn better exposes the eggs to currents of aerated water. Moreover, the microtubular surface pores are also variable in shape (Figs. 4-7), which may suggests that they reflect specific needs of their location on the egg ribbon (or that a variety of shaped pores all can function similarly). Another aspect of water acquisition by the microtubular network of egg ribbons of the European perch may be their more neutral buoyancy. Such eggs would be more likely draped over aquatic vegetation or sway in the water column receiving more oxygen needed during embryogenesis.
The gelatinous layer may constitute a mechanical protection of an egg. Although it may not seem mechanically resistant its extensive dimensions, combined with the turgidity within the microtubular network, could help to protect the developing embryo against sudden mechanical impacts.

\section{REFERENCES}

Bless R., Riehl R. 2002. Biology and egg morphology of the Dalmatian barbellgudgeon Aulopyge huegeli, an endangered endemic species in Croatia. Environmental Biology of Fishes 63: 451-456. DOI: 10.1023/A:1014992626062.

Bogucki N. 1930. Recherches sur la perméabilité des membranes et sur la presion osmotique des oeufs des salmonidés. Protoplasma 9: 345-369.

Bonsignorio D., Perego L., Del Giacco L., Cotteli F. 1996. Structure and macromolecular composition of the zebrafish egg chorion. Zygote 4: 101-108. DOI:10.1017/S0967199400002975.

Britz R., Bartsch P. 1998. On the reproduction and early development of Erpetoichthys calabaricus, Polypterus senegalus, and $P$. ornatipinnis (Actinopterygii: Polypteridae). Ichtyological Exploration of Freshwaters 9: 325-334.

Britz R., Cambray J.A. 2001. Structure of egg surfaces and attachment organs in anabantoids. Ichtyological Exploration of Freshwaters 12: 267-288.

Chen C.H., Wu C.C., Shao K.T., Yang J.S. 2007. Chorion microstructure for identifying five fish eggs of Apogonidae. Journal of Fish Biology 71: 913-919. DOI: 10.1111/j.1095$-8649.2007 .01527 . x$.

Chiou L.M., Chung M.C., Tung P.G., Hsu T., Yang J.S. 2004. The use of egg chorion glycoprotein of Epinephelus malabaricus for egg identification. Journal of Fish Biology 65: 1614-1621. DOI: 10.1111/j.0022-1112.2004.00571.x.

Davenport J., Lønning S. 1983. On the structure and function of the urogenital system of the female lumpsucker Cyclopterus lumpus L. (Teleostei: Scorpaeniformes). Proceedings of the Royal Society B 218 (1211): 201-210. DOI: 10.1098/rspb.1983.0034.

Davenport J., Lønning S., Kjørsvik E. 1986. Some mechanical and morphological properties of the chorions of marine teleost eggs. Journal of Fish Biology 29: 289-301. DOI: 10.1111/j.1095-8649.1986.tb04946.x.

Depêche J., Billard R. 1994. Embryology in fish: a review. Société Française d'Ichtyologie, Paris.

Fausto A.M., Picchietti S., Taddei A.R., Zeni C., Scapigliati G., Mazzini M., Abelli L. 2004. Formation of the egg envelope of a teleost, Dicentrarchus labrax (L.): Immunochemical and cytochemical detection of multiple components. Anatomy and Embryology 208: 43-53. DOI: 10.1007/s00429-003-0372-z.

Fava D., Toledo-Piza M. 2007. Egg surface structure in the annual fishes Simpsonichthys (subgenera Ophthalmolebias and Xenurolebias) and Nematolebias (Teleostei: Cyprinodontiformes: Rivulidae): variability and phylogenetic significance. Journal of Fish Biology 71: 889-907. DOI: 10.1111/j.1095-8649.2007.01572.x.

Fishelson L., Gon O. 2008. Comparative oogenesis in cardinal fishes (Apogonidae, Perciformes), with special focus on the adaptive structures of the egg envelopes. Environmental Biology of Fishes 81: 397-414. DOI: 10.1007/s10641-007-9211-z. 
Flügel H. 1967. Elektronenmikroskopische Untersuchung an den Hüllen der Oozyten und Eier des Flussbarches Perca fluviatilis. Cell and Tissue Research 77: 244-256. DOI: 10.1007/BF00340791.

Gillet C., Dubois J.P. 1995. A survey of the spawning of perch (Perca fluviatilis), pike (Esox lucius), and roach (Rutilus rutilus), using artifical spawning substrates in lakes. Hydrobiologia 300/301: 409-415. DOI: 10.1007/ /BF00024482.

Glauert A.M. 1981. Fixation, dehydration and embedding of biological specimens. Pp. 1-207. In: Glauert A.M. (ed) Practical methods in electron microscopy. Vol. 3. Part 1. Elsevier North-Holland Biomedical Press, Amsterdam, New York, and Oxford.

Jesuthasan S., Strähle U. 1997. Dymanic microtubules and specification of the zebrafish embryonic axis. Current Biology 7: 31-42. DOI:10.1016/S0960-9822(06)00025-X.

Jiang Y.-Q., Zhang T.-T., Yang W.-X. 2010. Formation of zona radiata and ultrastructural analysis of egg envelope during oogenesis of Chinese perch Siniperca chuatis. Micron 41: 7-14. DOI:10.1016/j.micron.2009.07.004.

Kobayashi W. 1982. The fine structure and amino acid composition of the envelope of the chum salmon egg. Journal of Faculty of Science Hokkaido University, Ser. 6, 23: 1-14.

Mansour N., Lahnsteiner F., Patzner R.A. 2008. Physiological and biochemical investigation on egg stickiness in common carp. Animal Reproduction Science 114: 256-268. DOI: 10.1016/j.anireprosci.2008.09.005.

Mansour N., Lahnsteiner F., Patzner R.A. 2009. Ovarian fluid plays an essential role in attachment of Eurasian perch, Perca fluviatilis eggs. Theriogenology 71: 586-593. DOI: 10.1016/j.theriogenology.2008.09.039.

Mikodina E.V. 1987. O structure poverhnosti oboloček ikrinok kostistyh ryb. [About the structure of egg envelopes of teleost fishes.] Voprosy Ihtiologii 27: 300-306. [In Russian.]

Mooi R.D. 1990. Egg surface morphology of Pseudochromoids (Perciformes: Percoidei), with comments on its phylogenetic implications. Copeia 2: 455-475.

Patzner R.A., Glechner R. 1996. Attaching structures in eggs of native fishes. Limnologica 26: 179-182.
Riehl R. 1978. Ultrastructure, development and significance of the egg membrane of teleosts. Rivista Italiana di Piscicotura e Ittiopatologia 13: 113-121.

Riehl R., Patzner R.A. 1998. Minireview: The modes of egg attachment in teleost fishes. Italian Journal of Zoology $\mathbf{6 5}$ (Suppl.): 415-420.

Riehl R., Schulte E. 1977. Vergleichende rasterelektronenmikroskopische Untersuchungen an den Mikropylen ausgewälter Süßwasser-Teleosteer. Archiv für Fischereiwissenschaft B 28: 95-107.

Rizzo E., Sato Y., Barreto B.P., Godinho H.P. 2002: Adhesiveness and surface patterns of eggs in neotropical freshwater teleosts. Journal of Fish Biology 61: 615-632. DOI: 10.1111/j.1095-8649.2002.tb00900.x.

Scapigliati G., Fausto A.M., Zega S., Mazzini M. 1995: Characterization of the main egg chorion proteins of the whitefish Coregonus lavaretus L. (Osteichthyes, Salmonidae). Comparative Biochemistry and Physiology - B: Biochemistry and Molecular Biology 112: 169-175. DOI: 10.1016/0305-0491(95)00043-8.

Schliwa M., Euteneuer U., Herzog W., Weber K. 1979. Evidence for rapid structural and functional changes of the melanophore microtubule-organizing center upon pigment movements. Journal of Cell Biology 83: 623-632.

Szulc J. 2007. Ultrastrukturalne osobliwości budowy osłon jajowych ryb na tle warunków ich naturalnego rozrodu. [Ultrastructural peculiarities of egg shells in relation the condition of to their natural reproduction.] Doctoral thesis, Agricultural University of Szczecin, Poland. [In Polish.]

Winnicki A. 1967. The turgor of salmonid fish eggs during hatching. Bulletin of the Polish Academy of Sciences, seria Biologia 12: 785-787.

Zeh M., Ritter E., Ribi G. 1989. Spawning and egg development of Perca fluviatilis in Lake Zürich. Aquatic Sciences 51: 100-107. DOI: 10.1007/BF00879297.

Received: 23 June 2009

Accepted: 10 November 2009

Published electronically: 10 December 2009 